\title{
Influence of Calcium and Phosphorus, Lactose, and Salt-to-Moisture Ratio on Cheddar Cheese Quality: pH Changes During Ripening
}

\author{
P. Upreti and L. E. Metzger ${ }^{1}$ \\ MN-SD Dairy Foods Research Center, Department of Food Science and Nutrition, University of Minnesota, St. Paul 55108
}

\section{ABSTRACT}

The $\mathrm{pH}$ of cheese is an important attribute that influences its quality. Substantial changes in cheese $\mathrm{pH}$ are often observed during ripening. A combined effect of calcium, phosphorus, residual lactose, and salt-tomoisture ratio $(\mathrm{S} / \mathrm{M})$ of the cheese on the changes in cheese $\mathrm{pH}$ during ripening was investigated. Eight cheeses with 2 levels of $\mathrm{Ca}$ and $\mathrm{P}(0.67$ and $0.47 \%$ vs. 0.53 and $0.39 \%$, respectively), lactose at pressing (2.4 vs. $0.78 \%)$, and $\mathrm{S} / \mathrm{M}(6.4$ vs. $4.8 \%)$ were manufactured. All the cheeses were salted at a $\mathrm{pH}$ of 5.4, pressed for $5 \mathrm{~h}$, and then ripened at 6 to $8^{\circ} \mathrm{C}$. The $\mathrm{pH}$ of the salted curds before pressing and the cheeses during $48 \mathrm{wk}$ of ripening was measured. Also, cheeses were analyzed for water-soluble $\mathrm{Ca}$ and $\mathrm{P}$, organic $\mathrm{P}$, and bound inorganic $\mathrm{P}$ during ripening. Changes in organic acids' concentration and shifts in the distribution of $\mathrm{Ca}$ and $\mathrm{P}$ between different forms were studied in relation to changes in $\mathrm{pH}$. Cheeses with low $\mathrm{S} / \mathrm{M}$ exhibited a larger increase in acid production during ripening compared with high S/M cheeses. Cheeses with the highest concentration of bound inorganic $\mathrm{P}$ exhibited the highest $\mathrm{pH}$, whereas cheeses with the lowest concentration of bound inorganic $\mathrm{P}$ exhibited the lowest $\mathrm{pH}$ among the 8 treatments. Although conversion of lactose to shortchain, water-soluble organic acids decreased cheese $\mathrm{pH}$, bound inorganic phosphate buffered the changes in cheese $\mathrm{pH}$. Production of acid in excess of the buffering capacity (which was the case in low $\mathrm{Ca}$ and $\mathrm{P}$ and low $\mathrm{S} / \mathrm{M}$ treatments) led to a low $\mathrm{pH}$, whereas solubilization of bound inorganic $\mathrm{P}$ in excess to acid production (which was the case in high $\mathrm{Ca}$ and $\mathrm{P}$ and high $\mathrm{S} / \mathrm{M}$ treatments) led to an increase in $\mathrm{pH}$. However, for cheeses with high $\mathrm{Ca}$ and $\mathrm{P}$ and low $\mathrm{S} / \mathrm{M}$, changes in cheese $\mathrm{pH}$ were influenced by the level of residual lactose. Hence, $\mathrm{pH}$ changes in Cheddar cheese can be modulated by a concomitant control on the amount and state of $\mathrm{Ca}$ and $\mathrm{P}$, level of residual lactose, and $\mathrm{S} / \mathrm{M}$ of the cheese.

Key words: Cheddar cheese, $\mathrm{pH}$, calcium, phosphorus

Received July 18, 2006.

Accepted August 31, 2006.

${ }^{1}$ Corresponding author: lmetzger@umn.edu

\section{INTRODUCTION}

Cheese $\mathrm{pH}$ influences almost all facets of cheese quality including flavor, texture, and appearance (Brown and Price, 1934; Dolby et al., 1937; Creamer et al., 1988; Pastorino et al., 2003). As an example, low pH $(<5.0)$ results in whey expulsion defects during ripening (Pastorino et al., 2003) and an increase in the rate of proteolysis (Lucey and Fox, 1993). Consequently, Lawrence et al. (1984) proposed $\mathrm{pH}$ as one of the compositional standards for grading Cheddar cheese, as well as a parameter for classifying different cheese varieties.

Cheese $\mathrm{pH}$ is not static and changes during ripening; and in most Cheddar cheeses the $\mathrm{pH}$ will decrease by 0.10 to $0.40 \mathrm{pH}$ units during pressing and the first several months of ripening (O'Connor, 1974; Sutherland and Jameson, 1981; Shakeel-Ur-Rehman et al., 2004). However, it is also common to observe an increase in Cheddar cheese $\mathrm{pH}$ during the first several months of ripening especially when concentrated milk is used to manufacture the cheese (Sutherland and Jameson, 1981; Acharya and Mistry, 2004). Changes in cheese $\mathrm{pH}$ during ripening are determined by the balance of production of different organic acids (mainly lactic acid) that causes a drop in $\mathrm{pH}$, and buffering capacity of the cheese that resists this change in $\mathrm{pH}$ (Lawrence and Gilles, 1982; Lawrence et al., 1984; Lucey and Fox, 1993; Hassan et al., 2004). Residual lactose in cheese is fermented by lactic acid bacteria to several short-chain, water-soluble organic acids that, upon dissociation, liberate $\mathrm{H}^{+}$and corresponding anions, causing a decrease in $\mathrm{pH}$. The rate and amount of acid produced depends on the salt-to-moisture ratio (S/M) and residual lactose present in the cheese (Turner and Thomas, 1980; Thomas and Pearce, 1981).

Buffering in cheese is related to the proteins and inorganic constituents (weak acids, bases, and metal ion complexes) present in cheese (Lucey and Fox, 1993; Salaün et al., 2005). Our recent investigations (Upreti et al., 2006a) as well as the investigations of other researchers (Hassan et al., 2004) have concluded that protein-bound calcium-phosphate complexes are the primary constituents controlling the buffering characteristics of a cheese. We have also completed a related study (Upreti and Metzger, 2006b) that developed and 
evaluated several techniques for measuring the various forms of $\mathrm{Ca}$ and phosphate in Cheddar cheese. However, there is no experimental evidence available in the literature that relates the changes in the various forms of $\mathrm{Ca}$ as well as phosphate in cheese during ripening to changes in cheese $\mathrm{pH}$ during ripening. The numerous forms of $\mathrm{Ca}$ and phosphate that can be present in cheese have been categorized in various ways and the nomenclature can be confusing. In this research we have differentiated $\mathrm{Ca}$ and $\mathrm{P}$ into soluble $\mathrm{Ca}$ and soluble $\mathrm{P}$, which are soluble in the serum phase of cheese, and bound $\mathrm{Ca}$ and $\mathrm{P}$, which are associated with the paracasein network in cheese. The bound $\mathrm{P}$ was further categorized into bound organic $P$, which is covalently attached to casein; and bound inorganic $P$, which is not covalently attached to casein but is entrapped by the paracasein network. Our investigation on mathematical modeling of the buffering curves of cheeses (Upreti et al., 2006a) indicated that the concentration of protein-bound calcium-phosphate complexes present in cheese is limited by the concentration of $\mathrm{P}$, rather than $\mathrm{Ca}$. Hence, we hypothesize that bound inorganic $\mathrm{P}$ has a key role in the buffering capacity of a cheese and that changes in the amount of bound inorganic phosphate during ripening will be related to changes in cheese $\mathrm{pH}$ during ripening.

Although the influence of $\mathrm{Ca}$ and $\mathrm{P}$, residual lactose, and $\mathrm{S} / \mathrm{M}$ individually on cheese $\mathrm{pH}$ is known (Turner and Thomas, 1980; Thomas and Pearce, 1981; Lucey and Fox, 1993), the objectives of this study were to determine the concomitant influence of $\mathrm{Ca}$ and $\mathrm{P}$, residual lactose, and $\mathrm{S} / \mathrm{M}$ on changes in cheese $\mathrm{pH}$ during ripening and to determine if changes in the form of $\mathrm{Ca}$ and phosphate during ripening are related to changes in cheese $\mathrm{pH}$.

\section{MATERIALS AND METHODS}

\section{Experimental Design}

Three replicates of Cheddar cheeses with 2 levels (high and low) of $\mathrm{Ca}$ and $\mathrm{P}$, residual lactose, and $\mathrm{S} / \mathrm{M}$ were manufactured. The 8 different treatments were high $\mathrm{Ca}$ and $\mathrm{P}-$ high lactose-high S/M (HHH); high Ca and P-high lactose-low S/M (HHL); high Ca and Plow lactose-high S/M (HLH); high Ca and P-low lactose-low S/M (HLL); low Ca and P-high lactose-high $\mathrm{S} / \mathrm{M}$ (LHH); low Ca and P-high lactose-low S/M (LHL); low $\mathrm{Ca}$ and $\mathrm{P}-$ low lactose-high S/M (LLH); and low Ca and P-low lactose-low S/M (LLL). Treatments with high levels of $\mathrm{Ca}$ and $\mathrm{P}$ were produced by setting the milk and drawing the whey at a higher $\mathrm{pH}$ (6.6 and 6.3 , respectively) compared with the treatments with low levels of $\mathrm{Ca}$ and $\mathrm{P}$ ( $\mathrm{pH}$ of 6.2 and 5.7, respectively). The lactose content in the cheeses was varied by adding lactose (2.5\% by weight of milk) to the milk for high lactose cheeses, and washing the curd for low lactose cheeses. The difference in $\mathrm{S} / \mathrm{M}$ was obtained by dividing the curds into 2 halves, weighing each half, and salting at 3.5 and $2.25 \%$ of the weight of the curd for high and low $\mathrm{S} / \mathrm{M}$, respectively. All cheeses were salted at a $\mathrm{pH}$ of 5.4, pressed for $5 \mathrm{~h}$, and then ripened at 6 to $8^{\circ} \mathrm{C}$. A detailed description of cheese manufacturing protocols followed to obtain the desired cheese composition is discussed elsewhere (Upreti and Metzger, 2006a). Average chemical composition of the 8 cheeses is shown in Table 1 . The cheeses were ripened for $48 \mathrm{wk}$, and changes in $\mathrm{pH}$, short-chain, water-soluble organic acids, water-soluble $\mathrm{Ca}$ and $\mathrm{P}$, organic $\mathrm{P}$, and bound inorganic $\mathrm{P}$ were monitored.

\section{pH Measurements}

The $\mathrm{pH}$ of the curds was measured before and after salting, and the $\mathrm{pH}$ of the cheeses was measured at $\mathrm{d}$ 1 , and at wk $1,2,3,4,8,16,32$, and 48 during ripening at 6 to $8^{\circ} \mathrm{C}$. Before $\mathrm{pH}$ measurement, the cheeses were finely ground using a blender (Osterizer Galaxie, Sunbeam Products, Inc., Boca Raton, FL), and tightly packed in 50-mL plastic snap-lid vials. In another vial, $20 \mathrm{~g}$ of ground cheese was weighed, and an $80 \%$ cheese:water slurry was made by adding $5 \mathrm{~g}$ of distilled water (Upreti et al., 2004). The $\mathrm{pH}$ of cheese and cheese slurry for the same sample were measured using a $\mathrm{pH}$ meter (Corning $\mathrm{pH} /$ ion meter 450, Corning, Woburn, MA) attached to 2 different precalibrated combination glass electrodes (Orion 91-02 pH electrode, Thermo Electron Corporation, Beverly, MA), and an automated temperature compensator. An average value of the 4 readings was recorded as the cheese $\mathrm{pH}$ for that sample. Cheese $\mathrm{pH}$ was measured directly as well as using the cheese slurry to substantiate the accuracy of the reported $\mathrm{pH}$ measurements (Upreti et al., 2004).

\section{Total Concentration of Short-Chain, Water-Soluble Organic Acids}

Nine different short-chain, water-soluble organic acids (citric, orotic, pyruvic, lactic, formic, uric, acetic, propanoic, and butanoic acids) were measured utilizing an HPLC-based method described by Zeppa et al. (2001), with suitable modifications (Upreti et al., 2006b). At all ripening times, the predominant watersoluble organic acid was lactic acid. The total organic acid content was calculated by adding the measured concentrations of the 9 organic acids for cheese curds after salting, and cheeses at d 1, and wk 1, 2, 3, 4, 8, 16,32 , and 48 during ripening. The concentration of each individual organic acid has been previously reported (Upreti et al., 2006b). 
Table 1. Average chemical composition of cheeses expressed as percentage by weight of cheese (mean of 3 replicates)

\begin{tabular}{|c|c|c|c|c|c|c|c|c|}
\hline & \multicolumn{8}{|c|}{ Treatment $^{1}$} \\
\hline & $\mathrm{HHH}$ & HHL & $\mathrm{HLH}$ & HLL & LHH & LHL & LLH & LLL \\
\hline Moisture & $32.07^{\mathrm{a}}$ & $33.80^{\mathrm{bc}}$ & $33.07^{\mathrm{ab}}$ & $35.21^{\mathrm{de}}$ & $34.08^{\mathrm{bcd}}$ & $35.94^{\mathrm{e}}$ & $34.39^{\mathrm{cd}}$ & $37.57^{\mathrm{f}}$ \\
\hline Fat & $35.93^{\mathrm{a}}$ & $34.95^{\mathrm{ab}}$ & $35.66^{\mathrm{ab}}$ & $34.75^{\text {abc }}$ & $34.48^{\mathrm{bcd}}$ & $33.62^{\text {cd }}$ & $34.67^{\mathrm{abc}}$ & $33.32^{\mathrm{d}}$ \\
\hline Protein & $26.40^{\mathrm{a}}$ & $25.55^{\text {abc }}$ & $26.02^{\mathrm{ab}}$ & $25.29^{\mathrm{bcd}}$ & $25.15^{\text {cd }}$ & $24.77^{\mathrm{cd}}$ & $25.29^{\mathrm{bcd}}$ & $24.46^{\mathrm{d}}$ \\
\hline Protein (dry basis $\left.{ }^{2}\right)$ & 38.87 & 38.60 & 38.88 & 39.02 & 38.16 & 38.67 & 38.54 & 39.18 \\
\hline Salt & $2.04^{\mathrm{bc}}$ & $1.68^{\mathrm{d}}$ & $2.14^{\mathrm{ab}}$ & $1.73^{\mathrm{cd}}$ & $2.28^{\mathrm{ab}}$ & $1.63^{\mathrm{d}}$ & $2.47^{\mathrm{a}}$ & $1.75^{\mathrm{cd}}$ \\
\hline Salt-in-moisture & $6.37^{\mathrm{a}}$ & $4.98^{\mathrm{b}}$ & $6.48^{\mathrm{a}}$ & $4.92^{\mathrm{b}}$ & $6.71^{\mathrm{a}}$ & $4.53^{\mathrm{b}}$ & $7.17^{\mathrm{a}}$ & $4.65^{\mathrm{b}}$ \\
\hline Lactose $(\mathrm{d} 1)$ & $1.52^{\mathrm{a}}$ & $1.35^{\mathrm{c}}$ & $0.32^{\text {de }}$ & $0.11^{\mathrm{e}}$ & $1.64^{\mathrm{ab}}$ & $1.41^{\mathrm{bc}}$ & $0.49^{\mathrm{d}}$ & $0.27^{\mathrm{e}}$ \\
\hline Total Ca & $0.69^{\mathrm{a}}$ & $0.68^{\mathrm{a}}$ & $0.67^{\mathrm{a}}$ & $0.66^{\mathrm{a}}$ & $0.55^{\mathrm{b}}$ & $0.54^{\mathrm{b}}$ & $0.55^{\mathrm{b}}$ & $0.51^{\mathrm{b}}$ \\
\hline Total P & $0.48^{\mathrm{a}}$ & $0.48^{\mathrm{a}}$ & $0.48^{\mathrm{a}}$ & $0.47^{\mathrm{a}}$ & $0.42^{\mathrm{b}}$ & $0.42^{\mathrm{b}}$ & $0.41^{\mathrm{b}}$ & $0.40^{\mathrm{b}}$ \\
\hline
\end{tabular}

${ }^{\mathrm{a}-\mathrm{f}}$ Means in a row with common superscripts do not differ $(P \geq 0.05)$.

${ }^{1}$ Treatments: $\mathrm{HHH}=$ high $\mathrm{Ca}$ and $\mathrm{P}$-high lactose-high S/M; HHL = high Ca and P-high lactose-low S/ $\mathrm{M} ; \mathrm{HLH}=$ high $\mathrm{Ca}$ and P-low lactose-high S/M; HLL = high Ca and P-low lactose-low S/M; LHH = low $\mathrm{Ca}$ and $\mathrm{P}-$ high lactose-high S/M; LHL = low Ca and P-high lactose-low S/M; LLH = low Ca and P-low lactose-high S/M; and LLL = low Ca and P-low lactose-low S/M.

${ }^{2}$ Percentage dry basis $=[$ Protein $\div(100-$ moisture $)] \times 100$.

\section{Water-Soluble Ca}

Water-soluble Ca was determined by the method described by Metzger et al. (2001) for cheeses at $d 1$, and wk $1,2,3,4,8,16,32$, and 48 during ripening. In this method, approximately $1.5 \mathrm{~g}$ of cheese was dispersed in $15 \mathrm{~mL}$ of distilled water (at $60^{\circ} \mathrm{C}$ ) using a high-shear mixer-homogenizer. The cheese-water dispersion was centrifuged (IEC HT centrifuge, International Equipment Company, Bedford, MA) at 7,000 $\times g$ for $10 \mathrm{~min}$. After centrifugation, the samples were held at $4^{\circ} \mathrm{C}$ for 10 min to solidify the top fat layer. The solidified fat layer was removed using a spatula, and the supernatant was filtered through Whatman no. 4 filter paper and the Ca content of the filtrate was determined using atomic absorption spectroscopy (model 1100B, Perkin Elmer Corporation, Wellesley, MA). The results were expressed as grams of water-soluble Ca per $100 \mathrm{~g}$ of cheese.

\section{Measurement of Different Forms of $\boldsymbol{P}$}

The different forms of $\mathrm{P}$ (i.e., water-soluble, organic, and bound inorganic $\mathrm{P}$ ) were determined at $\mathrm{d} 1$, and wk 1, 2, 3, 4, 8, 16, 32, and 48 during ripening. Total $\mathrm{P}$ in the cheeses was determined by ashing $\left(550^{\circ} \mathrm{C}\right.$ for 24 h) a 1-g cheese sample and colorimetrically determining the $\mathrm{P}$ content of the ash (AOAC, 1995; method number 991.25). Water-soluble $P$ was measured on the filtrate obtained for soluble $\mathrm{Ca}$ analysis using a colorimetric method (AOAC, 1995; method number 991.25). The concentration of bound organic $P$ was measured using a method we had previously developed (Upreti and Metzger, 2006b). This method utilizes $12 \%$ TCA to precipitate and isolate the casein present in cheese. Subsequently, this precipitate was ashed in the presence of calcium chloride and the $\mathrm{P}$ content of the ash was determined. The concentration of bound-inorganic $\mathrm{P}$ in cheese was determined by subtracting the measured values of water-soluble and organic $\mathrm{P}$ from the total $\mathrm{P}$ content of the cheese.

\section{Statistical Analysis}

A $2 \times 2 \times 2$ factorial model with 3 replications was used for statistical analysis. Changes in $\mathrm{pH}$; concentration of short-chain, water-soluble organic acids; water-soluble $\mathrm{Ca}$ and $\mathrm{P}$; organic $\mathrm{P}$; and bound-inorganic $\mathrm{P}$ during ripening were analyzed by using a repeated measures design (Table 2). The PROC GLM procedure of SAS (SAS Institute, 1990), which involved 3 factors (Ca and $\mathrm{P}$, residual lactose, and $\mathrm{S} / \mathrm{M}$ ) as class variables, was used for the data analyses. Simple linear and multiple regression analysis were performed using the PROC REG procedure of SAS (SAS Institute, 1990) to evaluate the relationship between water-soluble $\mathrm{Ca}$ and $\mathrm{P}$ and $\mathrm{pH}$.

\section{RESULTS AND DISCUSSION}

\section{Changes in Total Concentration of Short-Chain, Water-Soluble Organic Acids During Ripening}

The total concentration of short-chain, water-soluble organic acids during ripening was significantly $(P<$ 0.05 ) influenced by $\mathrm{S} / \mathrm{M}$, time, and the interaction of time $\times \mathrm{S} / \mathrm{M}$ (Table 2). These organic acids constitute different short-chain, water-soluble acids, namely citric, orotic, pyruvic, lactic, formic, uric, acetic, propanoic, and butanoic acids. A detailed description of the changes in the concentration of the individual acids during ripening has been published previously (Upreti 
Table 2. Mean squares (MS) and probabilities (in parentheses) of changes in total organic acids, $\mathrm{pH}$, water-soluble Ca and $\mathrm{P}$, organic $\mathrm{P}$ (per $100 \mathrm{~g}$ of protein), and bound inorganic $\mathrm{P}$ in Cheddar cheese during $48 \mathrm{wk}$ of ripening

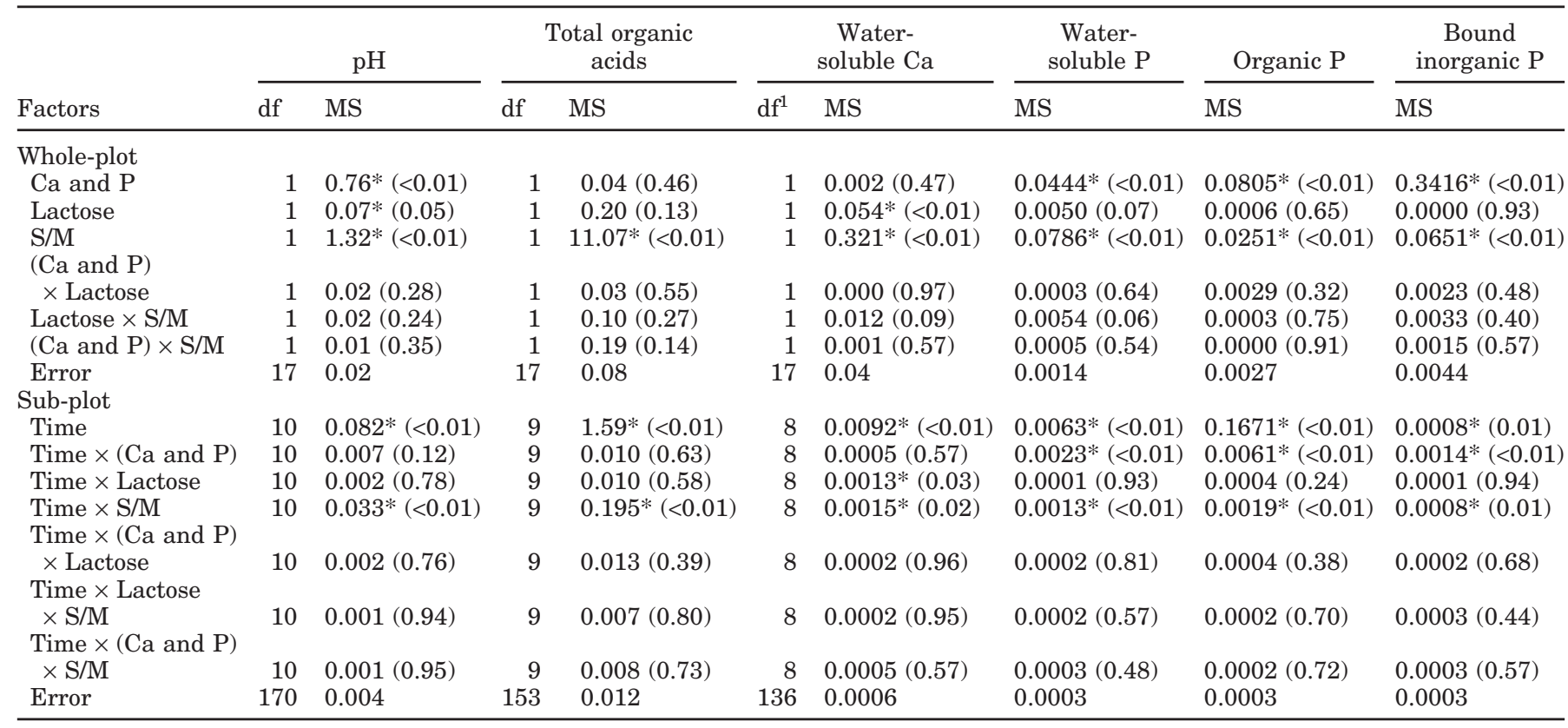

${ }^{1}$ Same $\mathrm{df}$ for water-soluble $\mathrm{Ca}$, and water-soluble, organic, and bound inorganic $\mathrm{P}$. $* P<0.05$.

et al., 2006b). Nonetheless, all of these acids, depending on their dissociation constants, will dissociate into $\mathrm{H}^{+}$ and corresponding anions, leading to a decrease in the $\mathrm{pH}$ of cheese.

As shown in Figure 1, the total concentration of shortchain, water-soluble organic acids was similar among the treatments immediately after salting and diverged during ripening. The largest increase in organic acids concentration in cheese was observed between salting and $\mathrm{d} 1$. Any increase thereafter was gradual. Cheeses with low S/M exhibited a larger increase in organic acids concentration compared with cheeses with high $\mathrm{S} / \mathrm{M}$, thus leading to a higher concentration of organic acids in low S/M treatments (HHL, HLL, LHL, LLL) vs. high S/M treatments (HHH, HLH, LHH, LLH) at the end of ripening. Likewise, Turner and Thomas (1980) observed a higher concentration of lactic acid in cheeses with low S/M. Increased fermentation of lactose to organic acids in case of low S/M treatments could be related to higher bacterial activity at low S/M.

\section{Changes in Water-Soluble Ca During Ripening}

Water-soluble Ca was significantly $(P<0.05)$ influenced by lactose, $\mathrm{S} / \mathrm{M}$, time, and the interactions of time $\times$ lactose, and time $\times \mathrm{S} / \mathrm{M}$ (Table 2 ). At $d 1$, water-soluble $\mathrm{Ca}(\mathrm{g} / 100 \mathrm{~g}$ of cheese) was highest in treatments with high lactose and low S/M (HHL, LHL) and lowest for treatments with low lactose and high S/M (HLH, LLH), irrespective of their total Ca content. However, during the first 2 wk of ripening, shifts in water-soluble $\mathrm{Ca}$ occurred, leading to differences in the concentration of water-soluble $\mathrm{Ca}$ among treatments throughout the remaining ripening period that were mainly governed by S/M and residual lactose (Figure 2). Thus, the concentration of water-soluble $\mathrm{Ca}$ in cheeses was significantly $(P<0.05)$ higher in treatments with low $\mathrm{S} / \mathrm{M}$ (HHL, HLL, LHL, LLL) vs. high S/M (HHH, HLH, LHH, LLH; Table 2 and Figure 2). In addition, watersoluble Ca was higher $(P<0.05)$ in treatments with high lactose compared with their corresponding low lactose treatments with (HHH vs. HLH, HHL vs. HLL, LHH vs. LLH, LHL vs. LLL). This could be due to the differences in organic acids produced in cheeses that differ in residual lactose and S/M (Figure 1). However, the effect of lactose will be influenced by the S/M, because $\mathrm{S} / \mathrm{M}$ influences the conversion of lactose into organic acids. Although an increase in water-soluble Ca during ripening has been reported (Metzger et al., 2001; Pastorino et al., 2003; Hassan et al., 2004), the influence of concomitant alteration of total $\mathrm{Ca}$, salt, and lactose content on water-soluble $\mathrm{Ca}$ has not been studied.

To characterize the shifts in the ratio of water-soluble $\mathrm{Ca}$ to total $\mathrm{Ca}$, water-soluble $\mathrm{Ca}$ can be reported as a percentage of total Ca (WSCTC). Our cheeses showed a large range of WSCTC. For instance, at d 1 in LHL cheese, WSCTC was $90 \%$, whereas in HLH, WSCTC was $50 \%$. Shifts in WSCTC have been related to corres- 
$\longrightarrow$ - HHH $\longrightarrow$ HHL $\longrightarrow \Delta-H L H ~-O-H L L$
$--\Delta-$ LHH -- LHL $--\Delta-$ LLH $--O-$ LLL
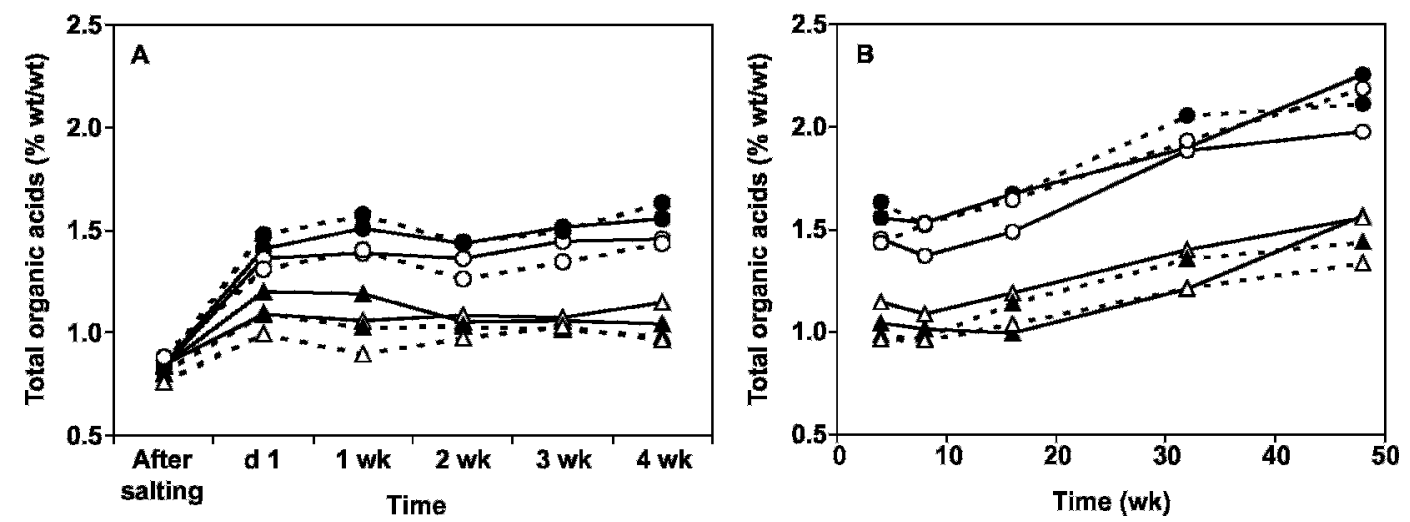

Figure 1. Changes in total organic acids content of cheeses during ripening (mean of 3 replicates). Treatments: $\mathrm{HHH}=$ high Ca and $\mathrm{P}-$ high lactose-high S/M; HHL = high Ca and P-high lactose-low S/M; HLH = high Ca and P-low lactose-high S/M; HLL = high Ca and Plow lactose-low S/M; LHH = low Ca and P-high lactose-high S/M; LHL = low Ca and P-high lactose-low S/M; LLH = low Ca and P-low lactose-high S/M; and LLL = low Ca and P-low lactose-low S/M. SEM $=7.75 \times 10^{-4}$.

ponding shifts in $\mathrm{pH}$ (Metzger et al., 2001; Pastorino et al., 2003; Hassan et al., 2004). To investigate this, calculated values of WSCTC were plotted as a function of $\mathrm{pH}$ for all cheeses at all ripening times used in this study (Figure 3a). Regression analysis demonstrated a linear relationship between WSCTC and cheese $\mathrm{pH}(\mathrm{r}=$ 0.78). This indicates that the observed changes in water-soluble $\mathrm{Ca}$ partially corresponded to changes in cheese $\mathrm{pH}$, although there appear to be other factors (such as proteolysis) that influence solubilization of $\mathrm{Ca}$ in cheese.

\section{Changes in Water-Soluble P During Ripening}

Water-soluble $\mathrm{P}$ was significantly $(P<0.05)$ influenced by $\mathrm{Ca}$ and $\mathrm{P}, \mathrm{S} / \mathrm{M}$, time, and the interactions of time $\times \mathrm{Ca}$ and $\mathrm{P}$, and time $\times \mathrm{S} / \mathrm{M}$ (Table 2). As shown in Figure 4, cheeses with low $\mathrm{Ca}$ and $\mathrm{P}$ (LHH, LHL, LLH, LLL) had higher levels of water-soluble $\mathrm{P}$ compared with their high $\mathrm{Ca}$ and $\mathrm{P}$ counterparts $(\mathrm{HHH}$, HHL, HLH, HLL). It was interesting to note that Ca and $\mathrm{P}$ did not have a significant $(P>0.05)$ influence on water-soluble $\mathrm{Ca}$, but did have a significant $(P<0.05)$
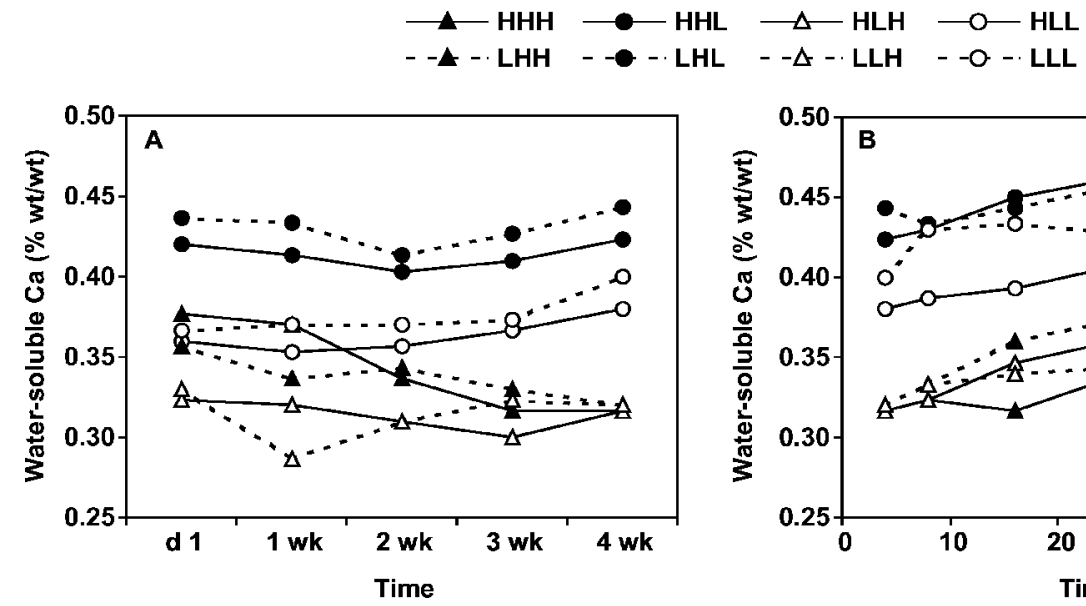
and P-high lactose-high S/M; HHL = high Ca and P-high lactose-low S/M; HLH = high Ca and P-low lactose-high S/M; HLL = high Ca and P-low lactose-low S/M; LHH = low Ca and P-high lactose-high S/M; LHL = low Ca and P-high lactose-low S/M; LLH = low Ca and $\mathrm{P}$-low lactose-high S/M; and LLL = low $\mathrm{Ca}$ and P-low lactose-low S/M. SEM $=4.08 \times 10^{-5}$. 

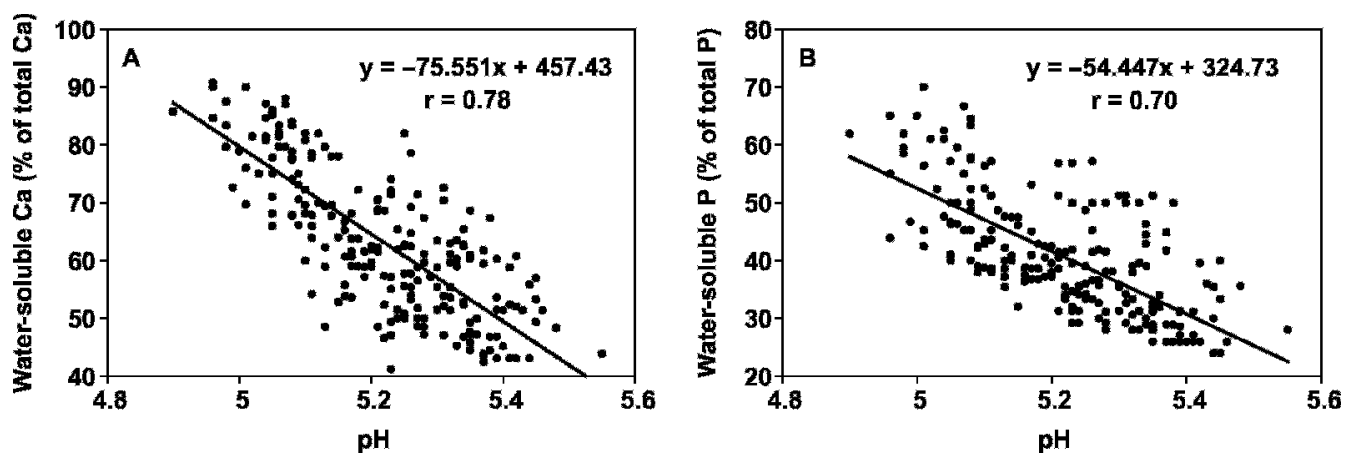

Figure 3. Concentration of water-soluble Ca (expressed as \% of total $\mathrm{Ca}$ ) and water-soluble $\mathrm{P}$ (expressed as \% of total $\mathrm{P}$ ) in cheeses as a function of $\mathrm{pH}$.

effect on water-soluble P. Moreover, cheeses with low $\mathrm{S} / \mathrm{M}$ had a higher concentration of water-soluble $\mathrm{P}$ compared with their high S/M counterparts (HHL vs. HHH, HLL vs. HLH, LHL vs. LHH, LLL vs. LLH), after the first 2 wk of ripening. There has not been a previous study on the shifts in water-soluble $\mathrm{P}$ in Cheddar cheese during ripening. However, previous studies conducted in milk or during cheese-making show that a decrease in $\mathrm{pH}$ causes an increase in water-soluble $\mathrm{P}$ (Dolby et al., 1937; Lucey and Fox, 1993).

To characterize the shifts in the ratio of water-soluble $\mathrm{P}$ to total $\mathrm{P}$, water-soluble $\mathrm{P}$ as a percentage of total $\mathrm{P}$ (WSPTP) was calculated. Calculations indicated that WSPTP was in the range of 30 to $45 \%$ at $d 1$, and diverged to give a range of 30 to $60 \%$ after $48 \mathrm{wk}$ of ripening (data not shown). To evaluate the relationship between WSPTP with respect to $\mathrm{pH}$, values of WSPTP were plotted as a function of $\mathrm{pH}$ for all the cheeses studied (Figure 3b). A regression analysis indicated a linear relationship between WSPTP and cheese $\mathrm{pH}(\mathrm{r}=$ $0.70)$. The regression line had a lower slope for WSPTP $(=54.45)$ compared with WSCTC $(=75.55)$, which indicated that there were differences in the relative solubilization of $\mathrm{Ca}$ compared with $\mathrm{P}$. The ratio of the slopes of the regression line of WSCTC and WSPTP is 1.39 $(75.55 \div 54.45=1.39)$. This indicates that, on average, for $1 \mathrm{~mol}$ of $\mathrm{P}, 1.39 \mathrm{~mol}$ of $\mathrm{Ca}$ is solubilized per unit change in $\mathrm{pH}$. A higher rate of solubilization of Ca compared with $\mathrm{P}$ with a decrease in $\mathrm{pH}$ has been reported by others (Dolby et al., 1937; Czulak et al., 1969; Lucey and Fox, 1993).

\section{Changes in Organic P During Ripening}

The concentration of organic $\mathrm{P}$ (per $100 \mathrm{~g}$ of protein) during ripening was significantly $(P<0.05)$ influenced

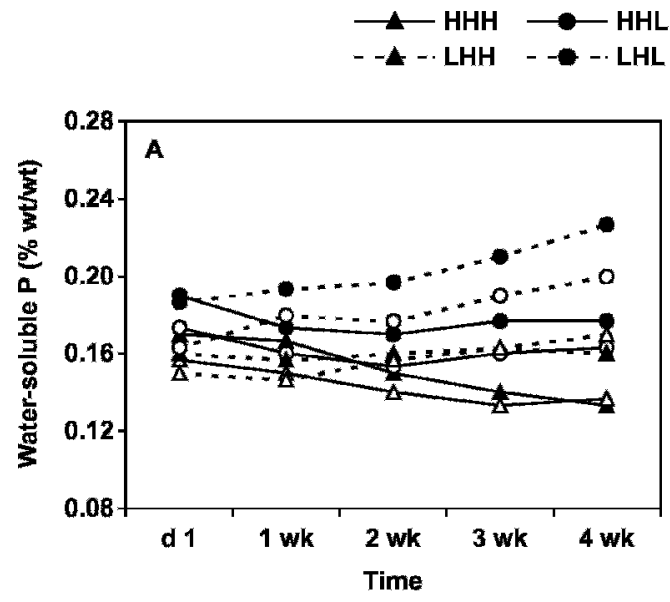

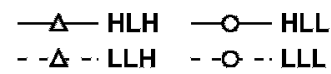

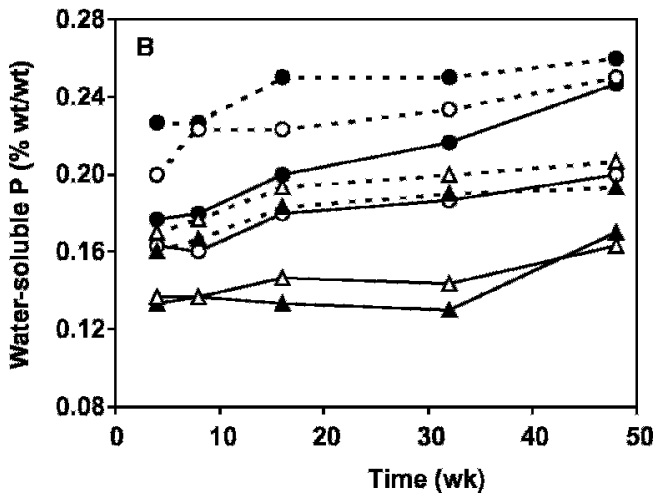

Figure 4. Changes in concentration of water-soluble $\mathrm{P}$ in cheeses during ripening (mean of 3 replicates). Treatments: $\mathrm{HHH}=\mathrm{high}$ Ca and P-high lactose-high S/M; HHL = high Ca and P-high lactose-low S/M; HLH = high Ca and P-low lactose-high S/M; HLL = high Ca and P-low lactose-low S/M; LHH = low Ca and P-high lactose-high S/M; LHL = low Ca and P-high lactose-low S/M; LLH = low Ca and P-low lactose-high S/M; and LLL = low Ca and P-low lactose-low S/M. SEM $=2.04 \times 10^{-5}$. 

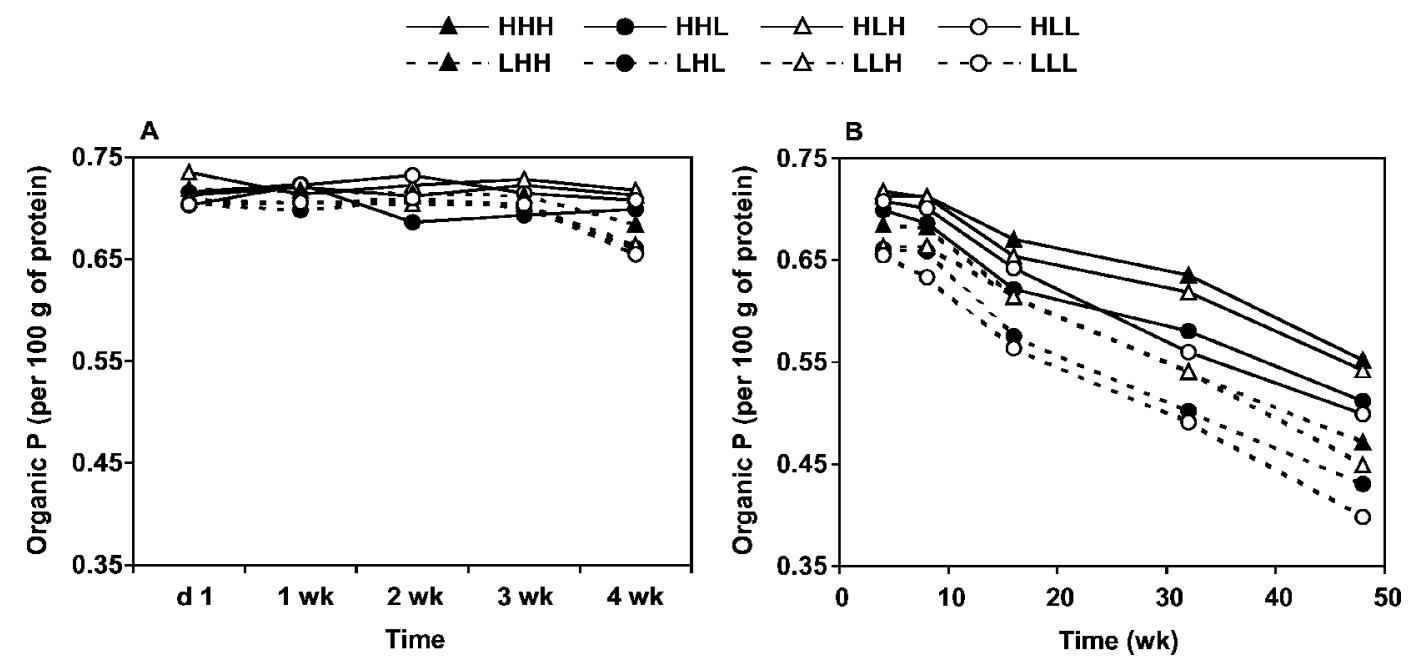

Figure 5. Changes in concentration of organic $\mathrm{P}$ (per $100 \mathrm{~g}$ of protein) in cheeses during ripening (mean of 3 replicates). Treatments: $\mathrm{HHH}=$ high $\mathrm{Ca}$ and P-high lactose-high S/M; HHL = high Ca and P-high lactose-low S/M; HLH = high Ca and P-low lactose-high S/M; HLL = high Ca and P-low lactose-low S/M; LHH = low Ca and P-high lactose-high S/M; LHL = low Ca and P-high lactose-low S/M; LLH = low $\mathrm{Ca}$ and $\mathrm{P}-$ low lactose-high $\mathrm{S} / \mathrm{M}$; and LLL = low Ca and P-low lactose-low S/M. SEM $=2.04 \times 10^{-5}$.

by $\mathrm{Ca}$ and $\mathrm{P}, \mathrm{S} / \mathrm{M}$, time, and the interactions of time $\times$ $\mathrm{Ca}$ and $\mathrm{P}$, and time $\times \mathrm{S} / \mathrm{M}$ (Table 2 ). The values for organic $\mathrm{P}$ have been reported per $100 \mathrm{~g}$ of protein to take into account the differences in the protein content of the cheese. As shown in Figure 5, there were minimal differences between the treatments during the first 4 wk of ripening, but there was a reduction in the level of organic $\mathrm{P}$ in all treatments during extended ripening. This decrease was larger in cheeses with low $\mathrm{Ca}$ and $\mathrm{P}$ (LHH, LHL, LLH, LLL) compared with cheeses with high $\mathrm{Ca}$ and $\mathrm{P}$ (HHH, HHL, HLH, HLL), and in the low S/M treatments compared with their high S/M counterparts (HHL vs. HHH, HLL vs. HLH, LHL vs. LHH, LLL vs. LLH). Our calculations indicate that at $d 1$, about 35 to $45 \%$ of the total $\mathrm{P}$ was present as organic $\mathrm{P}$, which decreased to 25 to $30 \%$ by $48 \mathrm{wk}$ of ripening. We are unaware of any previously published data on the changes in organic $\mathrm{P}$ during cheese ripening.

The observed decrease in organic $\mathrm{P}$ during the extended ripening period may be due to dephosphorylation of caseins and phosphopeptides because of the activity of acid phosphatases in cheese (Akuzawa and Fox, 2004). The activity of acid phosphatase has been found in Cheddar cheese (Dully and Kitchen, 1973; Andrews and Alichanidis, 1975), and consequently, several phosphopeptides and partly dephosphorylated peptides derived from caseins have been isolated from Cheddar cheese (Singh et al., 1997). Acid phosphatases can be derived from milk (Andrews and Alichanidis, 1975), or they can be a part of the proteolytic system of starter bacteria (Dully and Kitchen, 1973). However, it is not known whether indigenous or bacterial acid phospha- tases are responsible for dephosphorylation in cheese (Akuzawa and Fox, 2004). These enzymes are most active in the $\mathrm{pH}$ range of 4.5 to 5.5 (Akuzawa and Fox, 2004), which is the $\mathrm{pH}$ range observed in Cheddar cheeses. Akuzawa and Fox (2004) observed that acid phosphatase activity increases during Cheddar cheese ripening; this might explain the decrease in organic $\mathrm{P}$ in our cheeses.

The lower level of organic $\mathrm{P}$ in treatments with low S/M compared with the high S/M treatments could be a result of the higher water activity $\left(\mathbf{a}_{\mathbf{w}}\right)$ in the low $\mathrm{S} /$ M. Although the $a_{w}$ of the cheese in this study was not determined, previous research has described the effect of S/M on $a_{w}$ (Marcos et al., 1981). The potential difference in $\mathrm{a}_{\mathrm{w}}$ between the low and high salt treatments could have an effect on enzyme activity. Additionally, the low S/M treatments had a higher level of proteolysis (Upreti et al., 2006c), which may have increased the availability of phosphopeptides for dephosphorylation by phosphatases. In a similar manner, the low $\mathrm{Ca}$ and P treatments had a higher level of proteolysis compared with the high $\mathrm{Ca}$ and $\mathrm{P}$ treatments, which could have caused the lower level of organic $\mathrm{P}$ in the high $\mathrm{Ca}$ and $P$ treatments. Previous research has reported that free phosphates inhibit the activity of acid phosphatases (Akuzawa and Fox, 2004). As mentioned previously, the low $\mathrm{Ca}$ and $\mathrm{P}$ treatments had a higher level of watersoluble $\mathrm{P}$ compared with the high $\mathrm{Ca}$ and $\mathrm{P}$ treatments. Consequently, the low $\mathrm{Ca}$ and $\mathrm{P}$ treatments should have exhibited reduced phosphatase activity and had a higher level or organic phosphate, not the observed lower level of organic phosphate. These contradictory 

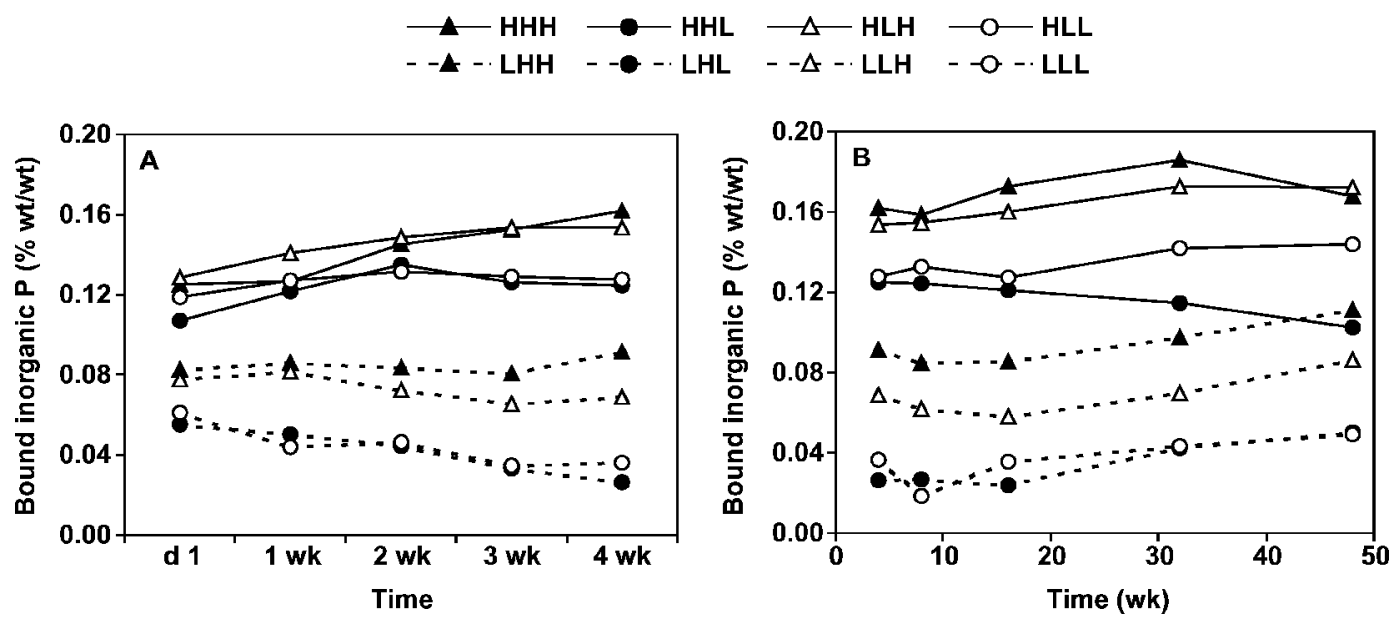

Figure 6. Changes in concentration of bound inorganic $\mathrm{P}$ in cheeses during ripening (mean of 3 replicates). Treatments: HHH $=$ high $\mathrm{Ca}$ and $\mathrm{P}-$ high lactose-high S/M; HHL = high Ca and P-high lactose-low S/M; HLH = high Ca and P-low lactose-high S/M; HLL = high $\mathrm{Ca}$ and P-low lactose-low S/M; LHH = low Ca and P-high lactose-high S/M; LHL = low Ca and P-high lactose-low S/M; LLH = low Ca and $\mathrm{P}-$ low lactose-high S/M; and LLL = low Ca and P-low lactose-low S/M. SEM $=2.04 \times 10^{-5}$.

results might be due to the fact that the influence of free phosphates on phosphatase activity reported by other researchers was measured in a controlled buffer system and not in cheese.

\section{Changes in Bound Inorganic P}

In the absence of an analytical method that directly measures bound inorganic $\mathrm{P}$ in cheese; the concentration of bound inorganic $\mathrm{P}$ was determined by subtracting the water-soluble and organic $\mathrm{P}$ from the total $\mathrm{P}$ concentration. Bound inorganic $\mathrm{P}$ during ripening was significantly $(P<0.05)$ influenced by $\mathrm{Ca}$ and $\mathrm{P}, \mathrm{S} /$ $\mathrm{M}$, time, and the interactions of time $\times \mathrm{Ca}$ and $\mathrm{P}$, and time $\times \mathrm{S} / \mathrm{M}$ (Table 2). As shown in Figure 6, cheeses with high $\mathrm{Ca}$ and $\mathrm{P}$ (HHH, HHL, HLH, HLL) had a higher amount of bound inorganic $\mathrm{P}$ compared with cheeses with low $\mathrm{Ca}$ and $\mathrm{P}$ (LHH, LHL, LLH, LLL). Similarly, cheeses with high S/M had a higher concentration of bound inorganic $\mathrm{P}$ than their corresponding low $\mathrm{S} / \mathrm{M}$ treatments (HHH vs. HHL, HLH vs. HLL, LHH vs. LHL, LLH vs. LLL), after the first 2 wk of ripening.

No previous research has investigated shifts in the concentration of bound inorganic $\mathrm{P}$ during ripening of Cheddar cheese. Our results demonstrate that bound inorganic $\mathrm{P}$ was highest in cheeses with high $\mathrm{Ca}$ and $\mathrm{P}$ and high $\mathrm{S} / \mathrm{M}$ (HHH and HLH) and lowest in cheeses with low $\mathrm{Ca}$ and $\mathrm{P}$ and low S/M (LHL and LLL). The cheeses with either high $\mathrm{Ca}$ and $\mathrm{P}$ and low S/M (HHL and HLL) or low $\mathrm{Ca}$ and $\mathrm{P}$ and high $\mathrm{S} / \mathrm{M}$ (LHH and $\mathrm{LLH}$ ) had bound inorganic $\mathrm{P}$ in the intermediate range. We believe that bound inorganic $\mathrm{P}$ is an indicator of the buffering capacity of cheese; hence, its implications on cheese $\mathrm{pH}$ may be important.

\section{Changes in pH During Ripening}

Cheese $\mathrm{pH}$ during ripening was significantly $(P<$ 0.05 ) influenced by $\mathrm{Ca}$ and $\mathrm{P}$, lactose, $\mathrm{S} / \mathrm{M}$, time, and the interaction of time $\times \mathrm{S} / \mathrm{M}$ (Table 2). As shown in Figure 7, all the cheeses were salted at a $\mathrm{pH}$ of $\sim 5.4$. The $\mathrm{pH}$ of the cheeses decreased at different rates during salting and pressing (from salting to $\mathrm{d} 1$ ) to produce cheeses with different $\mathrm{pH}$ at $\mathrm{d} 1$ (Figure 7a). The decrease in $\mathrm{pH}$ during salting and pressing was larger in treatments with low S/M compared with their high S/ M counterparts (HHL vs. HHH, HLL vs. HLH, LHL vs. LHH, LLL vs. LLH); and low $\mathrm{Ca}$ and $\mathrm{P}$ compared with their high $\mathrm{Ca}$ and $\mathrm{P}$ counterparts (LHH vs. HHH, LHL vs. HHL, LLH vs. HLH, LLL vs. HLL). This led to a higher $\mathrm{pH}$ in cheeses with high $\mathrm{Ca}$ and $\mathrm{P}$ and high $\mathrm{S} / \mathrm{M}$ (HHH and $\mathrm{HLH})$ and a lower $\mathrm{pH}$ in cheeses with low $\mathrm{Ca}$ and $\mathrm{P}$ and low S/M (LHL and LLL) at $\mathrm{d} 1$ and these differences were maintained throughout ripening (Figure 7). In the case of the cheeses with high $\mathrm{Ca}$ and $\mathrm{P}$ and low S/M, the treatment with low lactose (HLL) had a higher $\mathrm{pH}$ than the corresponding high lactose treatment (HHL) at $\mathrm{d} 1$ and throughout ripening (Figure 7).

It is worth noting (Figure 7a) that some treatments showed an increase in $\mathrm{pH}$ during the first $2 \mathrm{wk}$ of ripening. Our proposed reason for the observed increase in $\mathrm{pH}$ during ripening will be discussed in the subsequent section. It is also interesting to note that even though all the cheeses were salted at a $\mathrm{pH}$ of 5.40 , after 48 


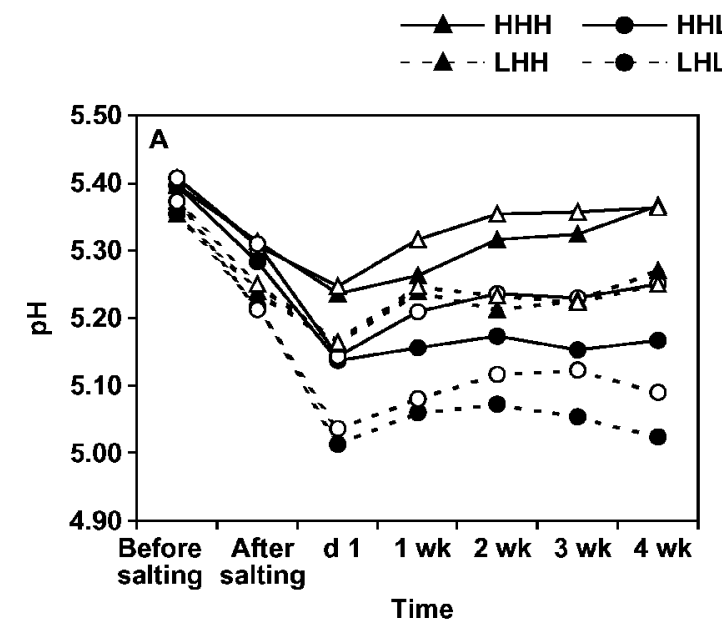

$-\triangle-H L H-O-H L L$
$--\triangle-$ LLH $--O-$ LLL

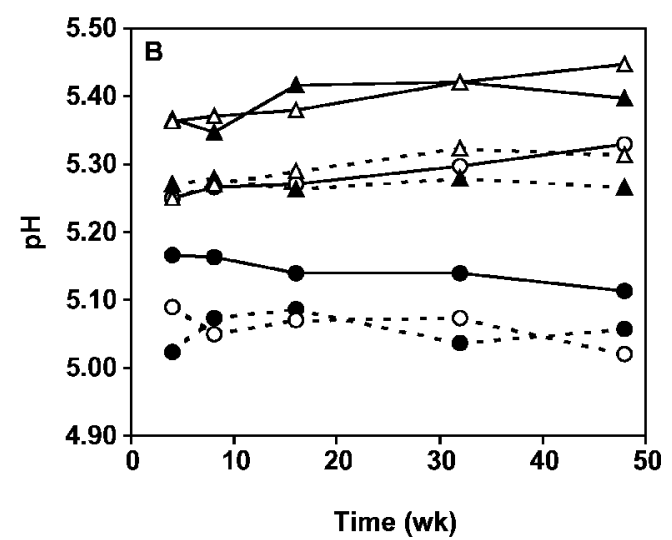

Figure 7. Changes in $\mathrm{pH}$ of cheeses during ripening (mean of 3 replicates). Treatments: $\mathrm{HHH}=$ high Ca and $\mathrm{P}-\mathrm{high}$ lactose-high $\mathrm{S} / \mathrm{M}$; $\mathrm{HHL}=$ high $\mathrm{Ca}$ and $\mathrm{P}-$ high lactose-low $\mathrm{S} / \mathrm{M} ; \mathrm{HLH}=$ high $\mathrm{Ca}$ and P-low lactose-high $\mathrm{S} / \mathrm{M} ; \mathrm{HLL}=$ high Ca and $\mathrm{P}-$ low lactose-low S/M; $\mathrm{LHH}=$ low $\mathrm{Ca}$ and P-high lactose-high S/M; LHL = low Ca and P-high lactose-low S/M; LLH = low Ca and P-low lactose-high S/M; and $\mathrm{LLL}=$ low $\mathrm{Ca}$ and P-low lactose-low S/M. SEM $=2.46 \times 10^{-4}$.

wk of ripening the final $\mathrm{pH}$ ranged from 5.00 to 5.45, depending upon the $\mathrm{Ca}$ and $\mathrm{P}$, residual lactose, and $\mathrm{S} /$ $\mathrm{M}$ of each cheese (Figure 7). Cheeses with high $\mathrm{Ca}$ and $\mathrm{P}$ were manufactured by setting the milk and draining the whey at a higher $\mathrm{pH}$ compared with the low $\mathrm{Ca}$ and $\mathrm{P}$ cheeses (Upreti and Metzger, 2006a). A similar influence of change in set/drain $\mathrm{pH}$ on the final cheese $\mathrm{pH}$ is well established (Dolby, 1941). According to Dolby (1941), a lower $\mathrm{pH}$ at draining results in a lower $\mathrm{pH}$ of the final cheese. They attributed this difference to the differences in the buffering capacity of the cheese, as contributed by the mineral content of the cheese (Brown and Price, 1934; Dolby et al., 1937).

The effect of residual lactose on cheese $\mathrm{pH}$ has been reported by Huffman and Kristoffersen (1984), who showed that the $\mathrm{pH}$ of cheeses with high lactose was lower than cheeses with low lactose. A more recent study by Shakeel-Ur-Rehman et al. (2004) found that the $\mathrm{pH}$ of cheeses with 0.25 and $0.61 \%$ residual lactose remained almost constant throughout $180 \mathrm{~d}$ of ripening, but for cheeses that contained $2.20 \%$ lactose, the $\mathrm{pH}$ decreased continuously throughout ripening, and dropped to 4.8 from its $\mathrm{pH}$ of 5.25 on d 1 . Additionally, in an effort to control the $\mathrm{pH}$ of cheese made using ultrafiltration retentates, Sutherland and Jameson (1981) found that 16 -wk $\mathrm{pH}$ values can be controlled by modifying the retentate lactose level, provided the $\mathrm{pH}$ buffering capacity of the retentate is similar. However, it is worth mentioning that lactose does not directly influence $\mathrm{pH}$ of cheese. Lactose leads to a decrease in $\mathrm{pH}$ only if it is converted to different shortchain organic acids by the action of lactic acid bacteria, which is related to the $\mathrm{S} / \mathrm{M}$ of cheese. In our study, differences in $\mathrm{pH}$ due to lactose were only observed in cheese with high $\mathrm{Ca}$ and $\mathrm{P}$ and low $\mathrm{S} / \mathrm{M}$.

The influence of $\mathrm{S} / \mathrm{M}$ on cheese $\mathrm{pH}$ has been well established. O'Connor (1974) found that for 8-wk-old Cheddar cheese, an $\mathrm{S} / \mathrm{M}$ of 1.4 to $4.9 \%$ resulted in a $\mathrm{pH}$ of 5.08 to 5.12; and an S/M of 6.3 to $8.3 \%$ resulted in a $\mathrm{pH}$ of 5.41 to 5.49. Subsequent investigations conducted by Thomas and Pearce (1981) indicated a strong correlation $(\mathrm{r}=0.94)$ between cheese $\mathrm{pH}$ and $\mathrm{S} / \mathrm{M}$, and between lactose concentration and $\mathrm{pH}(\mathrm{r}=0.96)$ at $14 \mathrm{~d}$ after manufacture. They also stated that at low $\mathrm{S} / \mathrm{M}(<4 \%)$, the $\mathrm{pH}$ of the cheese reaches a lowest limiting value, corresponding to the complete conversion of lactose to lactic acid. However, at high S/M ( $>6 \%)$, metabolism of lactose is severely inhibited, and hence high $\mathrm{pH}$ values are observed in Cheddar cheeses made with high salt content. Thomas and Pearce (1981) agreed that the possibility of variations of moisture in cheese due to variations in salt and its influence on lactose metabolism could be expected to influence changes in cheese $\mathrm{pH}$. However, in their study, they observed weaker correlations between moisture and residual lactose, or moisture and $\mathrm{pH}$, and concluded that it seems unlikely that moisture, per se, has an important effect, and $\mathrm{S} / \mathrm{M}$ is a comparatively more important parameter.

\section{Relationship Between the Form of $\mathrm{Ca}$ and $\mathrm{P}$ and Changes in Cheese pH During Ripening}

It is clear that changes in cheese $\mathrm{pH}$ during ripening of Cheddar cheese are a consequence of the balance of fermentation of lactose to organic acids that causes a drop in $\mathrm{pH}$, and buffering capacity of the cheese that 
resists this change in $\mathrm{pH}$. The acids produced dissociate into $\mathrm{H}^{+}$and corresponding ions causing a decrease in $\mathrm{pH}$. This decrease in $\mathrm{pH}$ is buffered by buffering agents in cheese. Because the cheeses in our study had similar protein contents on a dry basis (Table 1), any differences in buffering capacity should be attributed to the differences in the concentration of $\mathrm{Ca}$ and phosphate entrapped in the paracasein cheese network.

Our previous research (Upreti et al., 2006a) indicated that $\mathrm{Ca}$ and phosphate entrapped by the paracasein cheese network are chemically either hydroxyapatite $\left[\mathrm{Ca}_{5}(\mathrm{OH})\left(\mathrm{PO}_{4}\right)_{3}\right]$ or tricalcium phosphate $\left[\mathrm{Ca}_{3}\left(\mathrm{PO}_{4}\right)_{2}\right]$, or a mixture of both. Hence, the constituent phosphate ions (bound inorganic phosphate) present in the paracasein exist as $\mathrm{PO}_{4}^{3-}$ electrostatically bonded to $\mathrm{Ca}^{2+}$. Depending on the $\mathrm{pH}$, phosphate can exist in various forms $\left(\mathrm{PO}_{4}^{3-}, \mathrm{HPO}_{4}^{2-}, \mathrm{H}_{2} \mathrm{PO}_{4}^{-}\right.$, or $\left.\mathrm{H}_{3} \mathrm{PO}_{4}\right)$ that have corresponding $\mathrm{pKa}$ values of $2.12,7.21$, and 12.30 . The relative concentration of each form can be determined using the Hendersen-Hasselbach equation. We believe that the bound inorganic phosphate present in the $\mathrm{Ca}$ and phosphate entrapped by the paracasein network in cheese exists in a state of quasi-equilibrium and any process that disrupts this entrapped $\mathrm{Ca}$ and phosphate such as lactic acid production (which solubilizes the $\mathrm{Ca}$ and phosphate) or proteolysis (which disrupts the paracasein cheese network) exposes the entrapped $\mathrm{Ca}$ and phosphate to the serum phase of cheese. The bound inorganic phosphate released by this disruption is in the form of $\mathrm{PO}_{4}^{3-}$ and buffers any potential change in cheese $\mathrm{pH}$. As an example, the serum phase of a typical Cheddar cheese at salting is approximately $\mathrm{pH} 5.4$, which is between the phosphate pKa values of 2.12 and 7.12. Consequently, any released inorganic phosphate $\left(\mathrm{PO}_{4}^{3-}\right)$ would equilibrate to a mixture $\mathrm{HPO}_{4}^{2-}$ and $\mathrm{H}_{2} \mathrm{PO}^{4-}$ by accepting $\mathrm{H}^{+}$and would buffer any change in $\mathrm{pH}$ caused by production of additional lactic acid or other organic acids.

Although all the cheeses in this study were salted at a $\mathrm{pH}$ of 5.4, there were substantial differences in the $\mathrm{pH}$ by $\mathrm{d} 1$. A substantial reduction in $\mathrm{pH}$ from salting to $\mathrm{d} 1$ was observed in all treatments and corresponded to a rapid increase in total organic acids from salting to cheese at d 1 (Figure 1a). This production of acid should lead to immediate solubilization of $\mathrm{Ca}$ and phosphate entrapped by the cheese paracasein network, which would act as a buffer and should resist the decrease in $\mathrm{pH}$. However, there appears to be a delay in the solubilization of $\mathrm{Ca}$ and phosphate entrapped by the cheese paracasein network. Hence, after the initial drop in $\mathrm{pH}$ between salting and $\mathrm{d} 1$, all treatments showed an increase in $\mathrm{pH}$ between $\mathrm{d} 1$ and 14 (Figure 7a). The delay in the solubilization of entrapped $\mathrm{Ca}$ and phosphate may be due to restricted mobility and its slow equilibration in cheese. If during this equilibration, there is excess bound inorganic phosphate that can solubilize to an extent corresponding to lactic acid produced, it will completely buffer the change in $\mathrm{pH}$ and the cheese will equilibrate close to the original salting $\mathrm{pH}$. This appears to occur in the HHH and HLH treatments (Figures 6 and 7). However, if there is slightly more acid produced and less bound inorganic phosphate, it will lead to a lower $\mathrm{pH}$ after equilibration. This appeared to occur in the LHL and LLL treatments (Figures 6 and 7). Additionally, it is possible that the gradual increase in $\mathrm{pH}$ observed in some treatments (HHH, HLH) during later ripening may be related to the slow gradual release of bound inorganic phosphate as a result of proteolysis. Finally, if there is a substantial amount of acid production throughout ripening, as was the case in the HHL treatment (Figure 1), a slow but steady solubilization of bound inorganic $\mathrm{P}$ (Figure 8) will occur and the $\mathrm{pH}$ will remain stable until the bound inorganic $\mathrm{P}$ is exhausted.

This situation is analogous to our previous experiments (Upreti et al., 2006a), in which we added acid at different rates to the cheese:water dispersion and decreased the $\mathrm{pH}$ to 5.0 from its initial $\mathrm{pH}$. We observed that when $\mathrm{pH}$ was decreased at a faster rate, there was not enough time for entrapped $\mathrm{Ca}$ and phosphate to solubilize, which, on subsequent equilibration, led to a larger increase in $\mathrm{pH}$ compared with when the $\mathrm{pH}$ was decreased slowly. A slower titration provided enough time for entrapped $\mathrm{Ca}$ and phosphate to dissolve, and $\mathrm{pH}$ equilibration to occur. Our study indicates that $\mathrm{pH}$ equilibration in cheeses, due to acid production before $d$ 1 , occurs during the first $14 \mathrm{~d}$ of ripening (also apparent from shifts in water-soluble $\mathrm{Ca}$ ). Cheese $\mathrm{pH}$ seemed to be relatively stable at $14 \mathrm{~d}$; hence, subsequent changes in $\mathrm{pH}$ were small and governed by acid production and proteolysis during ripening.

\section{CONCLUSIONS}

Changes in Cheddar cheese $\mathrm{pH}$ during ripening are a consequence of the balance between acid production and buffering by displacement of $\mathrm{Ca}^{2+}$ by $\mathrm{H}^{+}$from phosphate entrapped by the cheese paracasein network. The state of phosphate appears to be related to cheese $\mathrm{pH}$ and cheese with a high level of bound inorganic phosphate has a high $\mathrm{pH}$, whereas cheese with a low level of bound inorganic phosphate has a low $\mathrm{pH}$. A decrease in $\mathrm{pH}$ during ripening is due to acid production in excess of the buffering capacity of cheese, whereas an increase in $\mathrm{pH}$ during ripening is due to solubilization of bound inorganic phosphate and the resulting buffering. These changes in cheese $\mathrm{pH}$ have implications for cheese qual- 

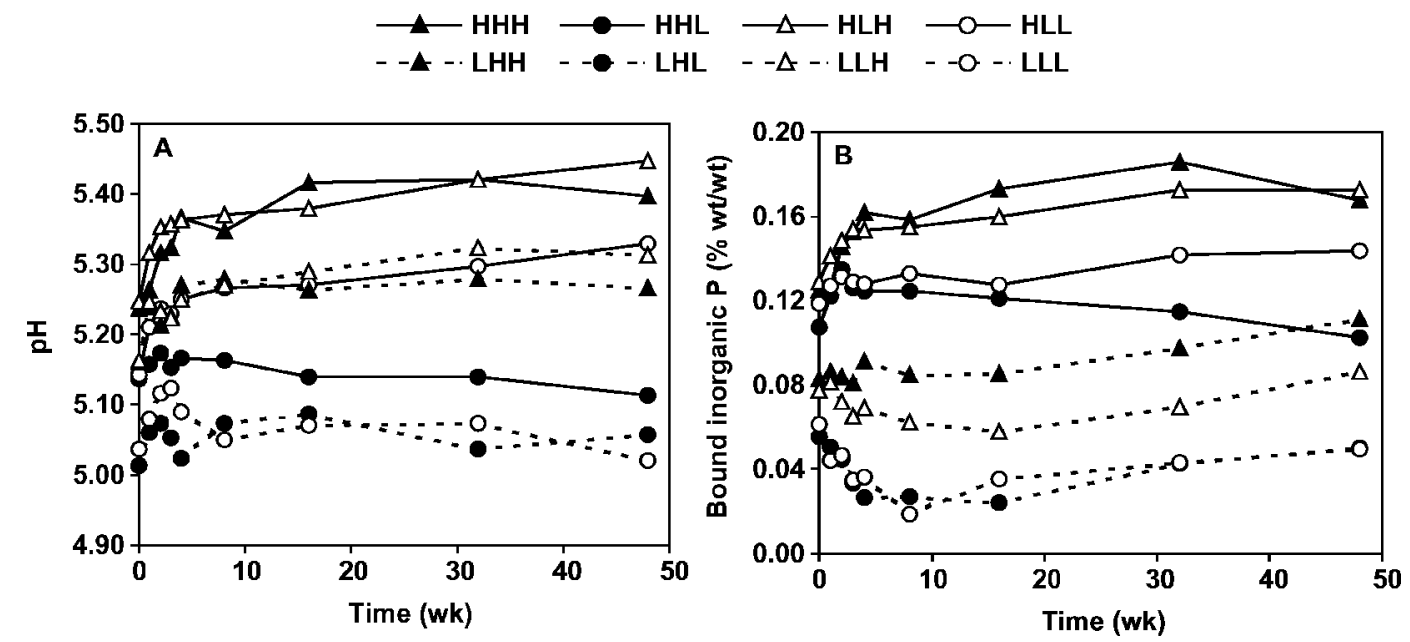

Figure 8. Changes in $\mathrm{pH}$ and bound inorganic $\mathrm{P}$ in cheeses during ripening (mean of 3 replicates). Treatments: $\mathrm{HHH}=$ high $\mathrm{Ca}$ and $\mathrm{P}-$ high lactose-high S/M; HHL = high Ca and P-high lactose-low S/M; HLH = high Ca and P-low lactose-high S/M; HLL = high Ca and Plow lactose-low S/M; LHH = low Ca and P-high lactose-high S/M; LHL = low Ca and P-high lactose-low S/M; LLH = low Ca and P-low lactose-high S/M; and LLL = low Ca and P-low lactose-low S/M.

ity (i.e., flavor, texture, and appearance). It is important for cheese manufacturers to recognize that cheese $\mathrm{pH}$ results from a balance of $\mathrm{Ca}$ and phosphate, residual lactose, and $\mathrm{S} / \mathrm{M}$ of the cheese. Hence, a concomitant approach to control $\mathrm{Ca}$ and phosphate, residual lactose, and $\mathrm{S} / \mathrm{M}$ should be pursued to control cheese $\mathrm{pH}$.

\section{ACKNOWLEDGMENTS}

We thank Dairy Management Inc. (Rosemont, IL), and Midwest Dairy Association (St. Paul, MN) for funding this project.

\section{REFERENCES}

Acharya, M. R., and V. V. Mistry. 2004. Comparison of effect of vacuum-condensed and ultrafiltered milk on Cheddar cheese. J. Dairy Sci. 87:4004-4012.

Akuzawa, R., and P. F. Fox. 2004. Acid phosphatase in cheese. Anim. Sci. J. 75:385-391.

Andrews, A. T., and E. Alichanidis. 1975. Acid phosphatase activity in cheese and starters. J. Dairy Res. 42:327-339.

AOAC. 1995. Official Methods of Analysis. 16th ed. Association of Official Analytical Chemists International, Arlington, VA.

Brown, L. W., and W. V. Price. 1934. A study of the relationships between hydrogen ion concentration, titratable acidity, and quality in Cheddar cheese. J. Dairy Sci. 17:33-45.

Creamer, L. K., J. Gilles, and R. C. Lawrence. 1988. Effect of pH on the texture of Cheddar and Colby cheese. N.Z. J. Dairy Sci. Technol. 23:23-35.

Czulak, J., J. Conochie, B. J. Sutherland, and H. J. M. Van Leeuwen. 1969. Lactose, lactic acid, and mineral equilibria in Cheddar cheese manufacture. J. Dairy Res. 36:93-101.

Dolby, R. M. 1941. The control of acid development in Cheddar cheesemaking. N.Z. J. Sci. Technol. 22:289A-302A.

Dolby, R. M., F. H. McDowell, and A. K. R. McDowell. 1937. Studies on the chemistry of Cheddar cheese making. V. Factors influencing the acidity and mineral content of cheese. J. Dairy Res. 8:74-85.
Dully, J. R., and B. J. Kitchen. 1973. The acid phosphatases of Cheddar cheese. Aust. J. Dairy Technol. 28:114-116.

Hassan, A., M. E. Johnson, and J. A. Lucey. 2004. Changes in the proportions of soluble and insoluble calcium during the ripening of Cheddar cheese. J. Dairy Sci. 87:854-862.

Huffman, L. M., and T. Kristoffersen. 1984. Role of lactose in Cheddar cheese manufacture and ripening. N.Z. J. Dairy Sci. Technol. 19:151-162.

Lawrence, R. C., and J. Gilles. 1982. Factors that determine the $\mathrm{pH}$ of young Cheddar cheese. N.Z. J. Dairy Sci. Technol. 17:1-14.

Lawrence, R. C., H. A. Heap, and J. Gilles. 1984. A controlled approach to cheese technology. J. Dairy Sci. 67:1632-1645.

Lucey, J. A., and P. F. Fox. 1993. Importance of calcium and phosphate in cheese manufacture: A review. J. Dairy Sci. 76:1714-1724.

Marcos, A., M. Alcalá, F. León, J. Fernández-Salguero, and M. A. Esteban. 1981. Water activity and chemical composition of cheese. J. Dairy Sci. 64:622-626.

Metzger, L. E., D. M. Barbano, and P. S. Kindstedt. 2001. Effect of milk preacidification on low fat Mozzarella cheese: III. Post-melt chewiness and whiteness. J. Dairy Sci. 84:1357-1366.

O'Connor, C. B. 1974. The quality and composition of Cheddar cheese. Effect of various rates of salt addition. III. Irish Agric. Creamery Rev. 27:11-13.

Pastorino, A. J., C. L. Hansen, and D. J. McMahon. 2003. Effect of $\mathrm{pH}$ on the chemical composition and structure-function relationships of Cheddar cheese. J. Dairy Sci. 86:2751-2760.

Salaün, F., B. Mietton, and F. Gaucheron. 2005. Buffering capacity of dairy products. Int. Dairy J. 15:95-109.

SAS Institute. 1990. SAS User's Guide: Statistics. Version 6.0 ed. SAS Institute Inc., Cary, NC.

Shakeel-Ur-Rehman, D. Waldron, and P. A. Fox. 2004. Effect of modifying lactose concentration in cheese curd on proteolysis and in quality of Cheddar cheese. Int. Dairy J. 14:591-597.

Singh, T. K., P. F. Fox, and A. Healy. 1997. Isolation and identification of further peptides in the diafiltration retentate of the watersoluble fraction of Cheddar cheese. J. Dairy Res. 64:433-443.

Sutherland, B. J., and G. W. Jameson. 1981. Composition of hard cheese manufactured by ultrafiltration. Aust. J. Dairy Technol. 36:136-143.

Thomas, T. D., and K. N. Pearce. 1981. Influence of salt on lactose fermentation and proteolysis in Cheddar cheese. N.Z. J. Dairy Sci. Technol. 16:253-259. 
Turner, K. W., and T. D. Thomas. 1980. Lactose fermentation in Cheddar cheese and the effect of salt. N.Z. J. Dairy Sci. Technol. 15:265-276

Upreti, P., P. Bühlmann, and L. E. Metzger. 2006a. Influence of calcium and phosphorus, lactose, and salt-to-moisture ratio on Cheddar cheese quality: $\mathrm{pH}$ buffering properties of cheese. J. Dairy Sci. 89:938-950.

Upreti, P., L. L. McKay, and L. E. Metzger. 2006b. Influence of calcium and phosphorus, lactose, and salt-to-moisture ratio on Cheddar cheese quality: Changes in residual sugars and water-soluble organic acids during ripening. J. Dairy Sci. 89:429-443.

Upreti, P., and L. E. Metzger. 2006a. Influence of calcium and phosphorus, lactose, and salt-to-moisture ratio on Cheddar cheese quality: Manufacture and composition. J. Dairy Sci. 89:420-428.
Upreti, P., and L. E. Metzger. 2006b. Utilization of FTIR spectroscopy for measurement of organic phosphorus and bound calcium in Cheddar cheese. J. Dairy Sci. 89:1926-1937.

Upreti, P., L. E. Metzger, and P. Bühlmann. 2004. Glass and polymeric membrane electrodes for the measurement of $\mathrm{pH}$ in milk and cheese. Talanta 63:139-148.

Upreti, P., L. E. Metzger, and K. D. Hayes. 2006c. Influence of calcium and phosphorus, lactose, and salt-to-moisture ratio on Cheddar cheese quality: Proteolysis during ripening. J. Dairy Sci. 89:444-453.

Zeppa, G., L. Conterno, and V. Gerbi. 2001. Determination of organic acids, sugars, diacetyl, and acetoin in cheese by high-performance liquid chromatography. J. Agric. Food Chem. 49:2722-2726. 